\title{
ZNAČILNOSTI TLORISA STANOVANJ IZ 20. STOLETJA (MARIBORSKA IZKUŠNJA)
}

dr. Vladimir Drozg

Oddelek za geografijo, Filozofska fakulteta Univerze v Mariboru

Koroška cesta I60, SI-2000 Maribor

e-mail: vlado.drozg@um.si

Izvirni znanstveni članek

COBISS 1.01

DOI: $10.4312 /$ dela.42.3.51-73

\section{Izvleček}

Prispevek obravnava tlorise stanovanj iz preteklega stoletja v Mariboru. Iz primerjave je razvidno, da se je zasnova stanovanja precej spremenila. Nekaj prostorov je nastalo na novo, nekaterih v novih stanovanjih ni več, spremenila se je tudi velikost prostorov. Prepoznani so trije tipi tlorisov: iz začetka 20. st., iz začetka druge polovice in iz konca stoletja. Spremembe tlorisa je mogoče povezati z značilnostmi meščanske družbe, socialističnim sistemom ter pojavom individualizma, blagostanja in potrošništva.

Ključne besede: bivanje, stanovanje, kulturna geografija, Maribor

\section{TRANSFORMATION OF THE 20TH CENTURY APARTMENT GROUND PLANS (MARIBOR CASE)}

\begin{abstract}
Comparing ground plans of apartments shows that their design and layout of rooms changed considerably during the last century. Some rooms were added, some others no longer exist, the size of rooms has also changed. There are three types of ground plans. One is from the beginning of the century, the other from the middle and the third from the end of the century. Changes of the ground plan can be linked to social characteristics of the bourgeois society, socialist system and the modern individualism and social wellbeing.
\end{abstract}

Key words: living, apartment, cultural geography, Maribor 


\section{UVOD}

Spoznavanje življenjskega prostora človeka, kar je predmet geografije, vključuje tudi bivalni prostor, katerega del je tudi stanovanje. Stanovanje je prostor, kjer bivamo, bivanje pa je ena od temeljnih človekovih dejavnosti. Doslej smo bivanje in stanovanje obravnavali predvsem s statističnimi podatki o številu prebivalcev in značilnostmi poselitve, stanovanje pa je (bilo) v geografiji redko predmet spoznavanja, kot da se prostor bivanja konča na ravni naselja, morda še na ravni stanovanjske hiše. Vendar je tudi stanovanje prostorsko in zato tudi geografsko relevantno, še posebej v luči novejše opredelitve vsebine geografije, ki govori o prostorskih razsežnostih človekovega delovanja, pri čemer nas $\mathrm{v}$ enaki meri kot dejavnost zanima tudi kraj, kjer se ta dejavnost odvija, ter nosilec, akter, ki dejavnost izvaja.

Stanovanje je odraz življenja in je pričevalno iz najmanj treh vidikov: kot fizična tvorba, ki se manifestira v tlorisu in je rezultat socialnih, ekonomskih in kulturnih razmer v družbi, kot socialni pojav, pri čemer je v ospredju oprema stanovanj in način bivanja v povezavi s socialnimi lastnostmi stanovalcev, ali kot kulturni pojav, pri čemer se osredotočamo na opremo stanovanja ter način bivanja $\mathrm{v}$ določenem časovnem ali regionalnem preseku. Stanovanje ima tudi ekonomsko vrednost, govorimo o trgu stanovanj, zato ga lahko obravnavamo še iz ekonomske plati. Ne nazadnje, stanovanje je kategorija s kulturno poanto, del kulture bivanja in človekove duhovnosti ter kot tako odraz (splošnih) družbenih in (ožjih) socialnih razmer na določenem območju.

Stanovanje je hkrati odraz gospodarskih, tehnoloških, kulturnih in socialnih razmer v družbi ter ekonomskih, socialnih in kulturnih lastnosti stanovalcev. Prva skupina dejavnikov se kaže v tlorisu, torej v velikosti, razporeditvi in vrsti prostorov. $\mathrm{V}$ tem kontekstu je stanovanje družbena kategorija, v kateri se zrcalijo vrednote, blagostanje skupnosti in splošne predstave o tem, kaj je pomembno za bivanje in kako to uprostoriti. Druga skupina dejavnikov se kaže v opremi stanovanja, povezana je namreč z načinom in kulturo bivanja oziroma socialnimi lastnostmi posameznika. V tem smislu je stanovanje »materializacija predstave o bivanju«, kot sta to opredelila Häußermann in Siebel (1996, str. 15). Seveda sta obe skupini dejavnikov spremenljivi kategoriji; spreminjata se $\mathrm{v}$ času in prostoru.

Stanovanje iz začetka 20. st. se močno razlikuje od današnjega ne le po opremljenosti in obliki, temveč po zasnovi. Spremembe zasnove stanovanja, velikosti in vrste prostorov, pa tudi njihova opremljenost, so svojevrstno ogledalo časa o bivalnem okolju, o načinu zadovoljevanja potreb, o družbenih vrednotah in socialnem položaju stanovalcev. Te razlike lahko razumemo kot spreminjanje kulturnogeografskih dejavnikov, okoliščin, ki generirajo specifične oblike (bivalnega) prostora. V nadaljevanju želimo prikazati značilnosti tlorisa stanovanj, ki so bila zgrajena v Mariboru v 20. st. ter ugotovljene lastnosti umestiti v kontekst družbenih razmer. Hkrati želimo osvetliti vsebinske in spoznavne razsežnosti bivanja ter spodbuditi zanimanje za to, doslej zapostavljeno tematiko. 


\section{KAJ JE STANOVANJE?}

Na način, kako bivamo, vpliva več dejavnikov. Stanovanje namreč ni zgolj domena stanovalca, temveč se v tlorisu odražajo tudi družbene - objektivne, od posameznika neodvisne okoliščine. Te so $\mathrm{v}$ domeni skupnosti, ki z gradbenimi normami predpisuje minimalna pravila, ki jih mora stanovanje izpolnjevati, da je primerno za zadovoljevanje potreb stanovalcev (npr. glede osončenosti, velikosti prostorov, funkcionalnosti). Od posameznika neodvisne so še splošne družbene razmere - družbena 'klima' - ki obsega vrednote, vlogo družine, položaj ženske in moškega v družbi, stopnjo delitve dela oziroma način življenja, tehnične zmožnosti opremljanja stanovanj z infrastrukturnimi sistemi (vodovodnim, kanalizacijskim in toplovodnim omrežjem, oskrba z energijo, oskrba z informacijami). Tudi oblika zazidanosti oziroma tip stanovanjske hiše vpliva na zasnovo stanovanja in način bivanja. Ti dejavniki se s časom spreminjajo, zato se spreminja tudi ureditev bivalnega okolja.

Druga skupina dejavnikov je v domeni posameznika. S socialnim položajem ter življenjskim stilom stanovalca $-\mathrm{z}$ materialnim, kulturnim in socialnim kapitalom (Bourdieu, 1987) - je povezana velikost, opremljenost in lokacija stanovanja, deloma tudi tip stanovanjske hiše. Isti tloris omogoča povsem različno opremljenost površin za bivanje, kar je povezano s socialnimi lastnostmi stanovalcev. Tloris je lupina, ki jo stanovalci uredijo in opremijo po svojih željah in predstavah. Na tej, bolj osebni ravni, lahko stanovanje pojmujemo kot skupek prostorov, ki omogočajo samostojno gospodinjstvo ter zadovoljevanje osnovnih potreb po počitku, higieni, intimnosti in zasebnosti (prirejeno po Häußermann, Siebel, 1996, str. 15; Müller, 1979, str. 93). Stanovanje je prostor družine, prostor nepoklicnega dela, simbol individualnosti, kraj, kjer hranimo svoje spomine in izkušnje. Tuan označuje stanovanje kot prostor varnosti, družinskosti in vzgoje (Tuan, 2004, str. 164). Hasse (2009, str. 27) izpostavlja emocionalni odnos med stanovalcem in krajem bivanja: besedi 'stanovati' in 'prebivati’ označujeta razliko med čustveno navezanostjo (na stanovanje) in vsakodnevno prisotnostjo na določenem kraju.

Tudi ta dimenzija stanovanja je geografsko relevantna. Povezana je namreč s socialnimi lastnostmi stanovalcev ali socialnih skupin, zato je lahko sredstvo pri spoznavanju socialno-prostorske diferenciacije stanovanjskih območij in načinov bivanja. Pogoste oznake, ki poudarjajo povezanost prostorskih in socialnih struktur, je zato potrebno razumeti ob upoštevanju dvojnosti 'socialnih razmer' - širših, ki se nanašajo na razmere v družbi, in tistih v ožjem smislu, ki se nanašajo na socialne lastnosti stanovalcev. Na to dvojnost opozarja tudi Studen (1995, str. 9), ko opisuje bivalne razmere v Ljubljani v začetku prejšnjega stoletja: »Bivanje se pri tem seveda ni nanašalo zgolj na individualni prostor in njegovo uporabo, marveč je bilo, kot že rečeno, tudi družbeni proces. Kako in zakaj so ljudje v določenem času in prostoru tako stanovali, je bilo v odločilni meri odvisno od družbenoekonomskih razmer, to pomeni, da je obstajala ozka povezanost med pripadnostjo različnim razredom in slojem na eni strani in izrabo stanovanja kot arhitektonskega in družbenega prostora na drugi strani. ... Bivanje pa je bilo odvisno tudi od regionalnih in časovno različnih tipičnih značilnosti.« 
Iz zapisanega lahko povzamemo ključne lastnosti in funkcije stanovanja:

- prostor, ki je odraz družbenih razmer, v stanovanju se odražajo vrednote družbe;

- prostor, ki je odraz socialnih lastnosti stanovalca;

- prostor, ki je namenjen zadovoljevanju človekovih potreb po higieni, intimnosti, pripravi hrane, počitku, zasebnosti, razvedrilu, stikih z bližnjimi;

- prostor, ki je namenjen shranjevanju in odlaganju osebnih stvari;

- prostor, ki varuje pred zunanjim svetom in vremenskimi vplivi;

- prostor, v katerem se izražata naša osebnost in način življenja;

- prostor, ki omogoča vsem članom gospodinjstva enake pogoje pri zadovoljevanju njihovih potreb.

Gornje navedbe so lahko izhodišče za opredeljevanje kazalcev, s katerimi je smiselno primerjati stanovanja med seboj, npr. v časovnem ali regionalnem preseku.

\section{METODA DELA}

Za ugotavljanje značilnosti tlorisov stanovanj je potrebno izbrati elemente (lastnosti), po katerih jih je možno primerjati med seboj in po katerih se stanovanja iz različnih obdobij preteklega stoletja razlikujejo. Pri tem smo izhajali iz funkcije stanovanja ter iz podatkov, ki jih je možno razbrati iz tlorisa. Vrsta in velikost prostorov, predvsem pa razmerja med njimi in njihovo spreminjanje skozi desetletja, se zdijo ključne lastnosti. Tako smo med relevantnimi elementi opredelili naslednje:

- vrsta in površina prostorov v stanovanju;

- razmerje med površino kuhinje in dnevne sobe;

- razmerje med površino dnevne sobe in spalnice;

- delež površine kopalnice v površini stanovanja;

- delež površine kuhinje v površini stanovanja;

- delež površine dnevne sobe v površini stanovanja;

- delež površine spalnice v površini stanovanja;

- prostori brez naravne svetlobe;

- število prehodnih sob (ki niso dostopne iz hodnika);

- ločena nočni in dnevni del stanovanja.

V nadaljevanju smo pridobili tlorise stanovanj, ki so bila zgrajena v različnih obdobjih prejšnjega stoletja. Pregledali smo 52 tlorisov, izmed katerih smo izbrali 23 takšnih, katerih razlike so precej očitne. Pri izboru smo upoštevali predvsem čas izgradnje stanovanja. Omejili smo se na stanovanja v večstanovanjskih hišah - blokih in večstanovanjskih meščanskih ter delavskih hišah, saj je izhodišče za načrt stanovanja bolj podobno kot pri enodružinskih hišah, kjer pridejo bolj do izraza želje in potrebe stanovalcev in s tem njihov življenjski stil. Upoštevali smo dvo- in trisobna stanovanja, prav tako z namenom, da bi bila stanovanja čim bolj primerljiva. Predvsem na začetku in na koncu 20. st. so nastajala stanovanja, ki so bila namenjena določenemu socialnemu sloju prebivalcev. Za objektivnejšo presojo smo zato upoštevali obe vrsti stanovanj. 
Podatke o površini ter namembnosti prostorov smo pridobili iz gradbene dokumentacije, ki jo hrani Pokrajinski arhiv Maribor (Gradbena dokumentacija stanovanjskih hiš ..., 2014). Opozoriti je potrebno na regionalni okvir besedila - spoznanja o spremembah tlorisov stanovanj ne prikazujejo razmer, ki bi bile specifične za Maribor. Prepričani smo, da jih je mogoče posplošiti na celotno Slovenijo, ker pa smo pregledovali samo tlorise mariborskih stanovanj, je regionalna omejitev besedila metodološko korektnejša. Ob tem se je potrebno zavedati, kar ugotavljata že Häußsermann in Siebel (1996, str. 23), da vsako prikazovanje sprememb v preteklosti nujno pomeni določeno stopnjo abstrahiranja oziroma poenostavljanja (redukcije) manj pomembnih vsebin. Kar ostane, lahko razumemo kot ključno značilnost ali osredje obravnavanega pojava.

\section{TRIJE TIPI STANOVANJ}

Pri spoznavanju tlorisov stanovanj v preteklem stoletju se je izkazalo, da lahko razlikujemo tri tipe, ki sovpadajo s tremi družbenimi obdobji: prvo polovico 20. st., ki ga v družbenem pogledu zaznamujeta meščanstvo in industrializacija, sredino druge polovice preteklega stoletja, ki ga zaznamujeta socialistični družbeni sistem in socialna enakost, ter koncem preteklega stoletja, ki ga določata naraščajoč individualizem ter potrošništvo. To ni periodizacija preteklega stoletja, zgolj oporne točke za prikaz sprememb tlorisa stanovanj.

\section{I. Stanovanje tipa A}

Prvo polovico prejšnjega stoletja sta zaznamovala meščanstvo in meščanska kultura. $\mathrm{Z}$ meščanstvom so povezane nove gospodarske dejavnosti, od trgovine in storitev do upravno-administrativnih služb, nove oblike delitve dela, nove vrednote, pa tudi nove oblike stanovanj, kakršnih v prejšnjih obdobjih ni bilo. Večstanovanjske meščanske hiše, vile, delavske hiše, mestne palače so značilne oblike zazidanosti iz konca 19. in začetka 20. st. Meščanska kultura je postavila norme vedenja in življenja ne le meščanskemu sloju prebivalcev, temveč tudi delu socialno nižjih slojev. Meščanske vrednote, kot so družina, poslovni uspeh, občutje in narava, so bile tako sredstvo lastne identitete kot element razlikovanja od drugih (Studen, 1995, str. 127). Navzven so se kazale kot reprezentativnost, posebnost vedenja, mišljenja ter drugačen način bivanja. Meščanska stanovanja so izkazovala moč, mogočnost, okus in družbeni položaj. Od tod veliki prostori, mogočna oprema, že vhod v stanovanje je moral narediti vtis na obiskovalca - zato je bila predsoba eden od glavnih reprezentativnih delov stanovanja. Poglavitna estetska usmeritev pri opremljanju (meščanskih) stanovanj je bila natrpanost, preobloženost. Fotografije in razglednice meščanskih stanovanj prikazujejo sobe, polne velikega, masivnega pohištva, kar naj bi vzbujalo tudi vtis obilja in družbenega položaja (Ferlež, 2009, str. 44).

V tem času se je povsem spremenilo pojmovanje družine. Nekdanja 'velika družina', ki je obsegala vse člane gospodinjstva, vključno z delovnim osebjem in sorodstvom, se je po novem skrčila na najožje družinske člane. To je bila gotovo posledica spremenjenega načina proizvodnje. $\mathrm{V}$ času, ko sta bila delo in bivanje združena pod isto streho, gospodarstvo pa je bilo v obliki manjših obrtnih in trgovskih enot, je bila (velika) družina 
tudi 'produkcijska enota' (Studen, 1995, str. 74). Ko se je proizvodnja prenesla v velike industrijske obrate, je proizvodna funkcija družine razpadla, ostala je le še 'privatna produkcija', kar označujemo kot začetek privatizacije družine (Studen, 1995, str. 74). To je prineslo nova razmerja med možem in ženo, novo organizacijo bivanja ter diferenciranost stanovanja, saj so se prostori za služinčad prostorsko ločili od prostorov za člane ožje družine. Meščanska kultura je pomenila poseben odnos med moškim in žensko in s tem povezane obveznosti moža in žene v skupnem gospodinjstvu. Moški je skrbel za preživetje družine in delovanje v javnosti, ženska pa za dobrobit družine in vzdrževanje družbenega položaja ter meščanskega reda.

Naslednja značilnost takratnih družbenih razmer, ki se odraža v tlorisu stanovanj, je samooskrba. Gospodinjstva v mestih so bila takrat v veliki meri samooskrbna, ne sicer toliko kot kmečka gospodinjstva na podeželju, pa vendar so veliko živil predelale gospodinje in gospodinjske pomočnice same, doma. Pri preskrbi z živili je prevladoval način 'na zalogo', hrambo. Za visoko stopnjo samooskrbe je bilo potrebno živila ustrezno hraniti in obdelati, za kar je bil potreben velik in opremljen prostor. Od tod potreba po veliki kuhinji in shrambi.

Tudi zaradi rasti mesta so se spremenile bivalne razmere. V 19. st. je bila infrastruktura v Mariboru še zelo pomanjkljiva, šele na prehodu v 20. st. se je pričela izgradnja vodovodnega in kanalizacijskega omrežja, s čimer so se močno izboljšale sanitarne razmere v stanovanjskih hišah in celotnem mestu. Po letu 1920 je bila večina stanovanjskih hiš že opremljena s kopalnico in straniščem na splakovanje. »Čist zrak, svetloba, ustrezna temperatura in brez vlage - poglavitne zdravstvene okoliščine vsakega stanovanja«, navaja Studen (1995, str. 46) kot glavno težavo stanovanjskih razmer v Ljubljani konec 19. st. V tem času je prišlo še do ločitve kraja dela od kraja bivanja, kar je tudi vplivalo na kakovost bivalnega okolja. Številne stanovanjske hiše so bile razbremenjene delavnic, skladišč in s tem povezanega hrupa in smradu. Tudi kokošnjaki in svinjaki, nekdaj pogosti na dvoriščih, so postajali vse redkejši pojav.

Seveda je bila takratna družba socialno razslojena, razlikujemo lahko vsaj med meščanskim in delavskim slojem. Socialna slojevitost se je odražala tudi v stanovanjih, najbolj v velikosti ter opremljenosti, pa tudi lokaciji in tipu stanovanjske hiše. Večstanovanjske meščanske hiše se bile praviloma bivališča meščanskih družin, čeprav je mogoče tudi znotraj hiše prepoznati socialno diferenciranost. Stanovanja v pritličju in na podstrehi so bila namenjena stanovalcem nižjega socialnega stanu, stanovanja v prvi in drugi etaži pa meščanom. Urejanje mest je bilo v začetku prejšnjega stoletja veliko bolj socialno naravnano, vsaj glede gradnje socialnih tipov stanovanj ter vzpostavljanja javnega in zasebnega prostora, tako da je bila razlika med meščanskimi in delavskimi stanovanji predvsem v lokaciji in velikosti stanovanjske površine ter opremi in ne toliko v konceptu (zasnovi) stanovanja.

Stanovanje iz začetka stoletja ima simetričen tloris, os simetrije predstavlja predsoba oziroma dolg hodnik, na vsako stran pa so razmeščeni prostori. Pirkovič Kocbek (1982, str. 62) je takšno zasnovo imenovala koridorski tip stanovanja. Stanovanje je običajno orientirano v smeri sever-jug, prostori so razporejeni tako, da je povsod naravna svetloba. Sobe so velike, brez vnaprej določene namembnosti. Kuhinja je samostojna soba; pri manjših stanovanjih je bila hkrati osrednji bivalni prostor, pri večjih je ta funkcija 
pripadala jedilnici. Takšen tloris povzema zasnovo meščanskih stanovanj iz 19. st. in se je obdržal do 50. let prejšnjega stoletja. Koridorski tip stanovanja je povezan s posebnim tipom hiše, in sicer z večstanovanjsko meščansko in delavsko hišo. Zanju je značilno, da sta $v$ eni etaži običajno dve stanovanji, tloris objekta pa je zrcalna preslikava po osrednjem stopnišču.

Slika 1: Koridorski tip meščanskega (levo) in delavskega stanovanja iz 20. let prejšnjega stoletja (desno): $s$-soba, $p$ - predsoba, $k$ - kuhinja, shr-shramba, $t$-toaleta, kop - kopalnica Figure 1: Corridor apartment type of bourgeois (left) and workers' house (right) from 1920s: $s$-room, $p$-anteroom, $k$ - kitchen, shr-pantry, $t$ - toilet, kop-bathroom

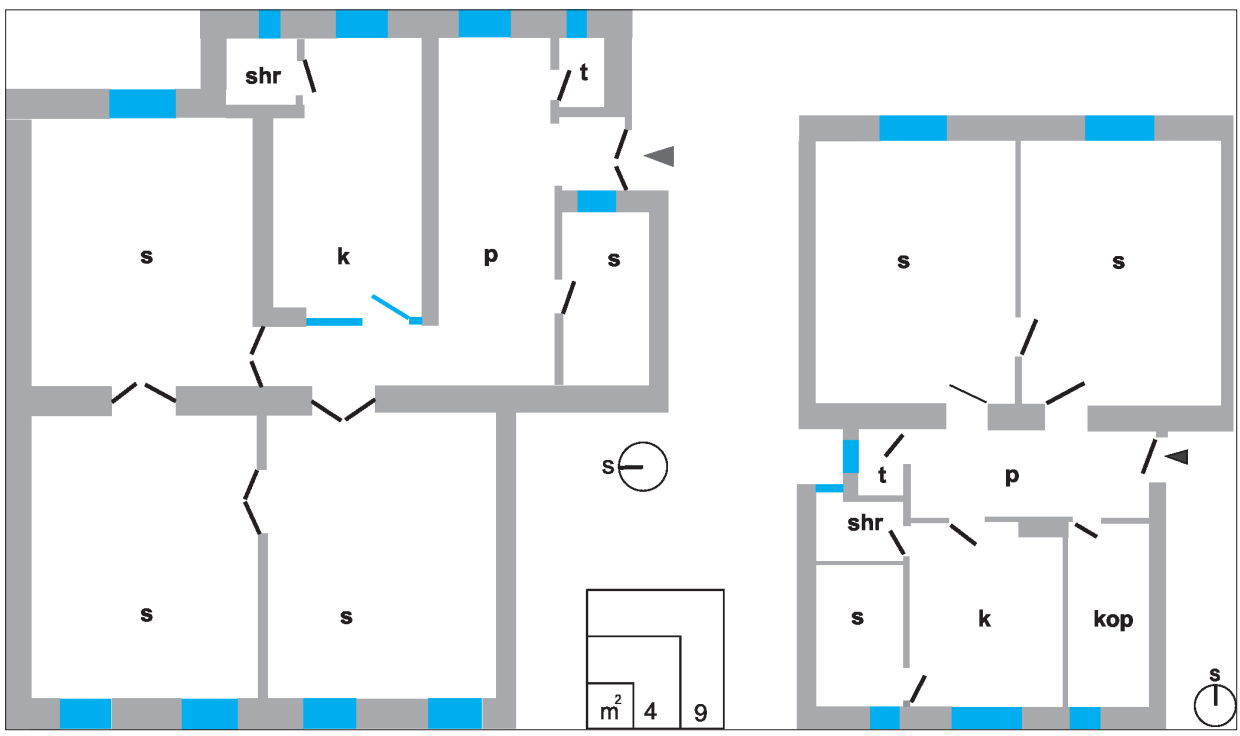

\subsection{Stanovanje tipa B}

Drugo polovico preteklega stoletja je zaznamoval socialistični družbeni sistem. Namesto socialne razslojenosti je bila v tem obdobju v ospredju socialna enakost. Socialni tipi bivališč so se v tem obdobju skoraj izgubili, nadomestila so jih poenotena stanovanja v stanovanjskih blokih in novih urbanih hišah. Glede na množičnost tovrstne gradnje stanovanj bi lahko govorili o nastajanju brezrazrednega stanovanja. V stanovanjski gradnji in oblikovanju bivalnega okolja se je uveljavil funkcionalistični princip - stanovanja so bila zasnovana tako, da je bila namembnost posameznih prostorov povsem prilagojena njihovi funkciji. Velikost in razmestitev prostorov je bila celo premišljena do te mere, da je gospodinja v kuhinji opravila čim manj odvečnih poti, da je velikost oken zadoščala za osvetlitev celotnega prostora, da je bila širina vrat prilagojena običajni dimenziji omare, prostornina sobe pa dimenzijam pohištva. Prostorske ureditve naj bi bile v prvi vrsti funkcionalne in racionalne, izvedljive v vsakem okolju. 
Pri gradnji stanovanj so veljali normativi o primerni površini posameznih prostorov, zato se je površina stanovanj precej zmanjšala. Le Corbusierova prispodoba o stanovanju kot 'stroju za bivanje' (machine-à-habiter) izraža navdušenost nad tehnično opremo in zmožnostmi, ki so prišle z mehanizacijo, avtomatizacijo in elektrifikacijo. Stanovanja so bila zasnovana po industrijskem principu kot prostori, v katerih je vse predvideno, podobno kot $\mathrm{v}$ industrijskem obratu, $\mathrm{v}$ katerem ni prostora za individualnost. Selle (2002, str. 216) govori o vdoru normativnosti in o približevanju idealu kolektivne produkcijske racionalnosti.

Tudi stanovanjska oprema je postala funkcionalna, prilagodljiva, pojavili so se tipski izdelki, ki jih je bilo mogoče sestaviti in razporediti na več načinov (npr. sobne regale). Pomembno vodilo pri oblikovanju opreme je bila ergonomija, oblika je postala podrejena funkciji, nekdanje organske vzorce so nadomestile čiste linije in geometrijske oblike. Tloris stanovanja je racionalen, noben prostor ni nesorazmerno velik ali nesorazmerno majhen, osrednji prostor v stanovanju je dnevna soba, iz katere so dostopni skoraj vsi ostali prostori. Pod vplivom idej funkcionalizma je nastala t. i. frankfurtska ali skandinavska kuhinja, kjer so bili prostori za gospodinjska opravila in s tem prostor gospodinje ločeni od drugih prostorov in članov družine. Tudi zaradi nasprotovanja feminističnih gibanj se je takšna zasnova kuhinje spremenila; kuhinja je od 70. let dalje ponovno bolj povezana $\mathrm{z}$ osrednjim bivalnim delom stanovanja.

Poleg zmanjšanja socialnih razlik med ljudmi je za to obdobje značilna rast blagostanja. Opremljenost gospodinjstev z gospodinjskimi aparati (pralnim strojem, televizorjem, hladilnikom) je v drugi polovici prejšnjega stoletja postala skoraj samoumevna. Isto velja za motoriziranost, kar je prav tako povečevalo občutek neodvisnosti, samostojnosti in individualnosti med ljudmi. Večje blagostanje se je kazalo tudi v boljši oskrbi s potrošnimi dobrinami, ob čemer so se spremenile oskrbovalne navade gospodinjstev in potreben čas za gospodinjska opravila. Zaradi večje ponudbe blaga se je nekdanja samooskrba gospodinjstev skrčila zgolj na sprotna gospodinjska opravila. Velika kuhinja ni bila več potrebna, tudi vsi pomožni prostori ne; velikost shrambe se je zato prepolovila ali pa jo je nadomestila omara kot del kuhinjske opreme.

Sredi 20. st. se je pričel uveljavljati individualizem, kar pomeni rahljanje nekdanjih lokalnih in družinskih skupnosti ter vse večjo samovoljo posameznika. Smisel življenja je postalo zadovoljevanje lastnih želja in potreb, pred željami in potrebami skupnosti. $\mathrm{V}$ primerjavi s tlorisi stanovanj iz začetka stoletja imajo nova stanovanja več prostorov (sob), nekateri so namenjeni družinskim članom, nekateri posebnim opravilom. Soba je postala pribežališče, kamor se je bilo mogoče umakniti pred drugimi. Del naraščajočega individualizma in rahljanja družinskih vezi je nov socialni položaj žensk in posredno tudi moških. Vse večja enakopravnost med spoloma je v veliki meri posledica zaposlovanja žensk. Vloga ženske ni bila več omejena na gospodinjska opravila in vzgojo otrok, podobno kot je bil oče razbremenjen odgovornosti za preživljanje družine. Odnosi v družini so postali enakopravnejši, način zunanje manifestacije socialnega položaja je iz stanovanja in stanovanjske opreme prešel na druge materialne dobrine, osebni avto, življenjski slog. 
Slika 2: Središčni tip stanovanja iz 70. (desno) in 80. let 20. st. (levo): s-soba, p-predsoba, $k$ - kuhinja, ds - dnevna soba, $t$ - toaleta, kop - kopalnica, $b$ - balkon

Figure 2: Central apartment type from 1970s (right) and 1980s (left): s-room, $p$-anteroom, $k$ - kitchen, $d s$ - living room, $t$ - toilet, kop - bathroom, b-balcony

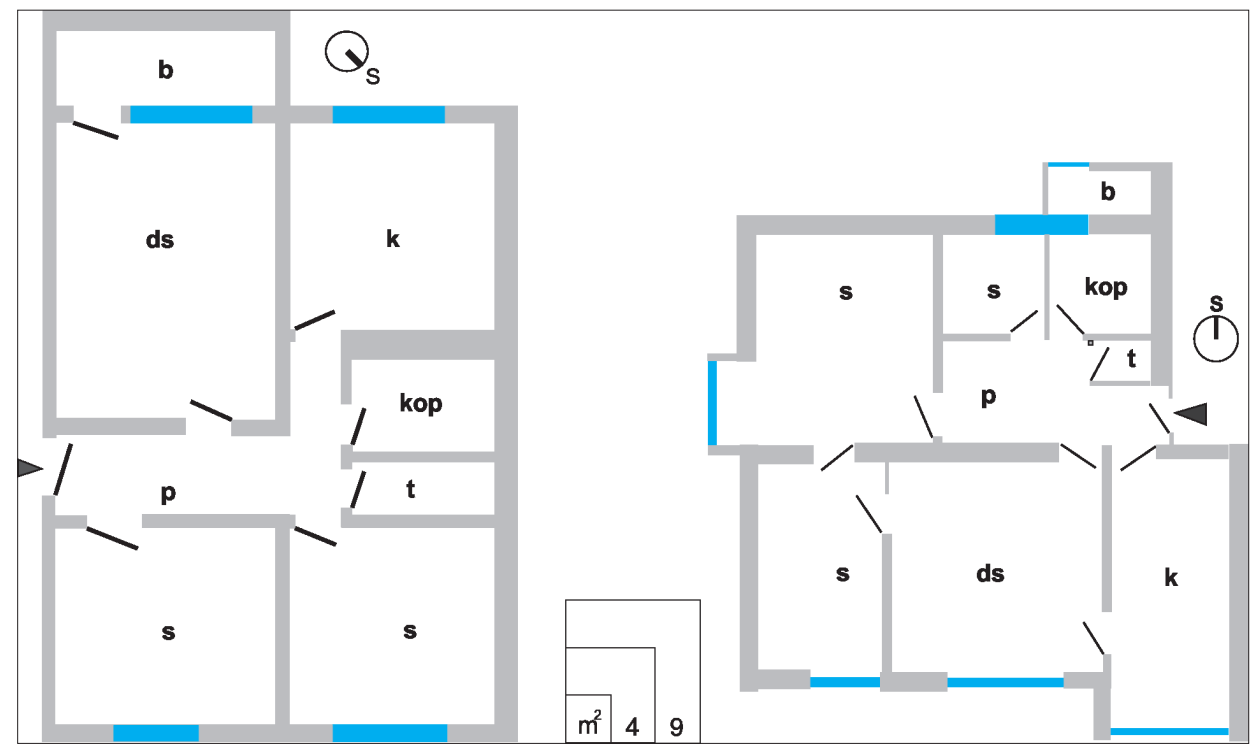

Tloris stanovanj iz druge polovice prejšnjega stoletja ima več posebnosti: osrednji prostor ni bila več (bivalna) kuhinja ali jedilnica, temveč dnevna soba. Od tod je možen dostop v skoraj vse druge prostore, kar je bila v prejšnjem tipu funkcija predsobe. Predsoba tudi ni bila več prostor povezovanja, temveč zgolj prostor vstopa v stanovanje. Izgubila je nekdanjo reprezentančnost in pridobila funkcionalnost. Število prehodnih sob se je zato povečalo, v vseh prostorih zaradi nove razporeditve ni bilo mogoče zagotoviti dnevne svetlobe. Značilno za ta tip tlorisa je še različna velikost prostorov, pri čemer namembnost določa velikost. Jedilnica je postala del kuhinje ali dnevne sobe in ni več samostojni prostor. Dnevni in nočni del stanovanja sta manj dosledno ločena. Tak tloris prepoznavamo v obdobju med 1950 in 1985-1990, imenovali pa bi ga lahko središčni (osredinjen) tip stanovanja; prostori so namreč razporejeni okoli dnevne sobe. Ta tip stanovanja je značilen za stanovanjske bloke in stolpnice, kjer je v eni etaži več stanovanj.

\subsection{Stanovanje tipa C}

Tloris stanovanj, kakršen je nastal ob koncu stoletja, prav tako odslikava nekaj družbenih značilnosti tistega časa. Morda najbolj očitna je preselitev velikega dela zasebnega življenja v stanovanje. To je postalo prostor dela, zabave, druženja, doživljanja, večfunkcionalni prostor, v katerem ljudje preživimo vedno več časa ali vsaj opravljamo veliko več stvari kot pred desetletji. Stanovanje je zasnovano tako, da postaja osrednji prostor 
v življenju (Prigge, 2002, str. 191). Temu je namenjen velik osrednji prostor, dnevna oziroma bivalna soba, razdeljena na več manjših delov, 'kotov' (medijski kot, jedilni kot, delovni kot). Sodobna tehnična oprema in informacijska tehnologija omogočata, da stanovanja ne zapustimo, a smo kljub temu v stiku z zunanjim svetom, tudi nakupovati je mogoče, ne da bi zapustili stanovanje.

Tudi življenje se odvija v drugačnem ritmu kot pred desetletji. Nekdanje jasno razmerje med delom in prostim časom za marsikatero socialno skupino ne velja več. Od obdobja industrializacije dalje se je delo vse bolj selilo iz stanovanjske hiše v posebne objekte - tovarne, urade, javne zgradbe. Stanovanje je ob tem postajalo vse bolj namenjeno preživljanju prostega časa in zasebnosti. Ob koncu 20. st. se je pričel obraten proces: zaradi razmaha storitvenih dejavnosti in informacijske tehnologije mnogo poklicev ni več vezanih na poslovno okolje in vse več dela je mogoče opravljati doma, v stanovanju. Morda zato ni več daleč čas, ko bosta dve delovni sobi postali povsem običajni del novodobnih stanovanj. Z razmahom storitvenih dejavnosti je zaznavno spreminjanje stanovanja v kraj dela. S t. i. 'delom na domu' stanovanje postaja tudi delovno mesto; bivanje in delovni prostor (pisarna) postajata ponovno povezana.

Po drugi strani postaja stanovanje zelo zaseben prostor, zatočišče pred razosebljenim, tekmovalnim in uničujočim zunanjim svetom, prostor doživljanja in sprostitve. Na to kažejo primeri vse bolj ekstravagantnih in nekonvencionalnih tlorisov, pa tudi stanovanjska oprema, pogosto izbrana s poudarjeno oblikovalsko vrednostjo. Pomembno vodilo opremljanja je postala 'atmosfera', vzdušje, ki ga stanovanje vzbuja, sredstvo za dosego tega pa so barva, materiali in oblika (Baudrillard, 2007, str. 42). Namesto nekoč prevladujočega lesa je v novih stanovanjih veliko umetnih materialov, kovine in stekla, nekdanje naravne barve je nadomestila živopisna barvna lestvica. Veliko opreme so tipizirani industrijski izdelki, ki zaradi obsežne ponudbe kljub temu omogočajo ustvariti stanovanje, prilagojeno individualnim predstavam in zahtevam stanovalca. Vse to odgovarja potrebi po ustvarjanju drugačnosti, vzpostavljanju in potrjevanju distance, odmaknjenosti od zunanjega sveta, od drugih. Frank Helten (2002, str. 67) omenja pojem 'connected isolation', kar pomeni, da je stanovalec preko informacijsko-komunikacijske tehnologije povezan v socialnih omrežjih, vendar lahko vsak trenutek iz njih tudi (začasno) izstopi. Prigge (2002, str. 191) vidi v sodobnih stanovanjih prostor, kamor se človek lahko umakne pred zunanjim svetom. »Stanovanje je kraj samouresničevanja.«

Za konec 20. st. je značilen tudi spremenjen odnos do narave. Sodobni človek želi živeti v stiku z naravo, jo 'spustiti' v svoj bivalni prostor. Morda bi lahko to težnjo prepoznali v velikih steklenih površinah (stenah) in velikem balkonu, ki je namenjen tudi počitku.

Ena pomembnejših družbenih značilnosti iz konca prejšnjega stoletja je socialna heterogenost in diferenciranost. Posledica blagostanja in potrošništva so raznolike in raznovrstne možnosti za karkoli in za kogarkoli, zato se je število življenjskih stilov, socialnih skupin in socialnih slojev zelo povečalo. Socialna heterogenost se kaže tudi v raznovrstnih načinih bivanja, še posebej v opremi stanovanj, zato je ponudba raznolikih stanovanj (z raznolikimi tlorisi) zelo velika. Hkrati se je še okrepil individualizem in s tem raznovrstnost načinov življenja oziroma zadovoljevanja potreb. V današnjem času je sprejemljivo vse, kar izrecno ne škodi sočloveku, sosedu, sodelavcu oziroma pravnemu redu. V socialnem pogledu se je 
povečala socialna diferenciranost, ki izhaja iz materialnega položaja gospodinjstva. Prav slednje je razlog za vse večjo diferenciranost načinov bivanja. Stanovanja se znova vse bolj razlikujejo glede na socialni status stanovalcev, kot je že bilo v začetku 20. st. Najbolj očitne so razlike v lokaciji, opremljenosti in nekonvencionalnosti tlorisa ter stanovanjskega objekta. Večje blagostanje pomeni vse manjšo samozadostnost gospodinjstev in vse večjo odvisnost od že pripravljenih dobrin (hrane, tipskega pohištva in druge stanovanjske opreme). Nekateri prostori so zaradi tega izgubili del nekdanjih funkcij (npr. kuhinja, shramba), nekateri pa ob tem pridobili nove (delovna soba, garderobna omara).

Družinske razmere označuje vse večja enakopravnost med spoloma, pa tudi vse bolj neformalni in sproščeni odnosi med starši in otroci. Vsaj na nivoju zasnove stanovanja ni mogoče prepoznati nekdanje družbene hierarhije, nasprotno, v sodobnem stanovanju ni več, pogojno rečeno, moških in ženskih prostorov, velikost in oprema kopalnice omogočata, da jo hkrati uporabljata dve osebi. Patriarhalnost zasnove stanovanja je oddaljena preteklost.

Slika 3: Primera odprtega tipa stanovanj iz konca 20. st.: s-soba, $p$ - predsoba, $k$-kuhinja, $d s$ - dnevna soba, $t$ - toaleta, kop - kopalnica, $b$ - balkon, ut - utility

Figure 3: Two types of open apartment from the end of last century: $s$-room, $p$-anteroom, $k$-kitchen, $d s$-living room, $t$-toilet, kop-bathroom, b-balcony, ut-utility

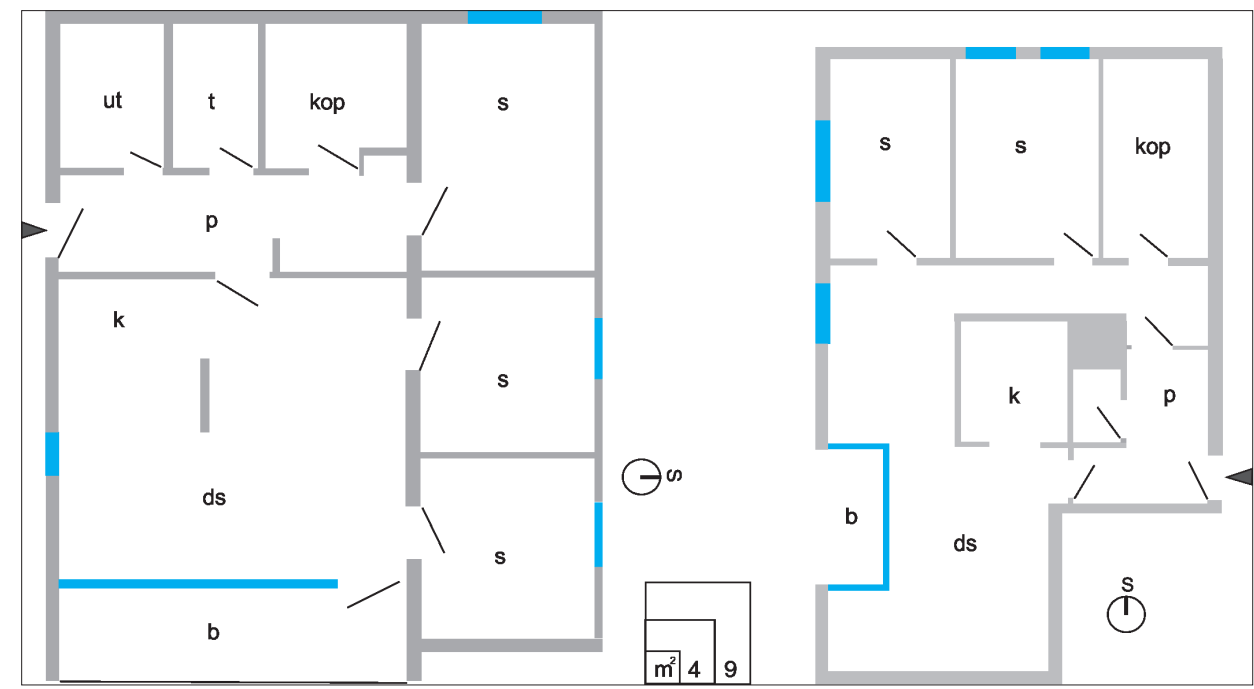

V stanovanju tipa $\mathrm{C}$ je ločene sobe, značilne za stanovanje iz prejšnjega obdobja, nadomestil velik skupni prostor, zaradi česar je stanovanje bolj odprto, vendar nudi stanovalcem manj zasebnosti. Nekdanje ločene prostore (delovna soba, otroška soba) v novih tlorisih nadomeščajo 'koti' (delovni kot, jedilni kot, medijski kot), ki so med seboj ločeni z delnimi stenami ali s pregradnimi stenami iz pohištva. Hkrati je nastalo več specializiranih prostorov, ki prej niso bili del stanovanja in so namenjeni posebnim opravilom (npr. utility, garderobna soba). Stanovanje deluje odprto in svetlo, k čemur pripomorejo 
steklene stene in velika okna, ki ustvarjajo bližnji stik z okolico. Razmerje med površino kuhinje in površino dnevne sobe je izrazito v prid slednje. Morda bi bil za tovrstna stanovanja ustrezen naziv odprti tip stanovanja z velikim osrednjim prostorom. Ta tip stanovanja se pojavlja v novejših večstanovanjskih blokih, stolpičih in stolpnicah.

\section{SPREMEMBE TLORISA STANOVANJV 20. STOLETJU}

\section{I. Površina stanovanja}

Med najbolj očitnimi spremembami v stanovanjih iz začetka in konca preteklega stoletja je velikost. Trisobno stanovanje iz začetka 20. st. obsega okoli $100 \mathrm{~m}^{2}$, enako velika stanovanja iz 70 . let merijo okoli $70 \mathrm{~m}^{2}$, stanovanja iz konca stoletja okoli $80 \mathrm{~m}^{2}$. Menimo, da je to povezano s spremembo osnovnega modula, to je drugačnega normativa o primerni velikosti sobe. V začetku stoletja so bile vse sobe velike med 20 in $25 \mathrm{~m}^{2}$, ne glede na socialni položaj lastnika stanovanja. Kasneje je 'osnovni modul' postajal vse manjši: v 70. letih je povprečna površina sobe znašala $17 \mathrm{~m}^{2}, 20$ let pozneje pa $20 \mathrm{~m}^{2}$. V stanovanjih iz začetka stoletja so bile vse sobe tudi približno enako velike, kasneje pa je bila velikost tesno povezana z namembnostjo. Otroška soba in spalnica sta bili praviloma manjši od povprečne velikosti, dnevna soba pa je postala večja. K manjši površini, denimo trisobnega stanovanja, sta veliko prispevali manjša predsoba in kuhinja. Takšne spremembe se običajno povezujejo z racionalnejšim tlorisom, čeprav sta enako pomembna tudi tip objektov ter spremenjene bivalne navade ljudi.

\subsection{Deli stanovanja $v$ začetku in ob koncu 20. stoletja}

$\mathrm{V}$ sto letih se je nabor prostorov, ki sestavljajo stanovanje, precej spremenil, vendar spremembe ne pomenijo novih funkcij, ki jih na začetku stoletja še ni bilo, ampak drugačno organizacijo življenja, ki je povezana s specializacijo prostorov. Kuhinja, dnevna soba in spalnica so bili na začetku in na koncu stoletja ključni deli stanovanj, spremembe se nanašajo na t. i. pomožne prostore (shramba, balkon, delovni prostor). Prostori, ki so bili sestavni del stanovanj do sredine 20. st., kasneje pa vedno redkeje, so shramba, bivalna kuhinja, gospodinjski balkon. Kopalnico so imela na začetku 20. st. le redka stanovanja, običajna je postala šele v 30 . letih. V začetku stoletja je bila v večjih stanovanjih obvezna soba za gospodinjsko pomočnico, česar v stanovanjih iz druge polovice stoletja ni več. Sredi stoletja, še bolj pa ob koncu stoletja, so se pojavili novi prostori, ki jih pred tem v takšni obliki ni bilo: balkon ali loža, kuhinjski kot, velika dnevna soba, ločena kopalnica in stranišče (v 60. letih), utility in garderobna soba (v 90. letih). Te spremembe so odraz spremenjenega načina življenja, pa tudi izboljšanja bivalnih razmer večine prebivalcev.

Od sredine stoletja dalje je shramba vse redkeje del stanovanja. Predpostavljamo, da je to posledica drugačne oskrbe z živili, pa tudi drugačnega načina obdelave in shranjevanja živil. V prvi polovici in tudi še sredi stoletja je bila ponudba živil v trgovinah zelo omejena. Gospodinje so velik del živil, predvsem ozimnico in sezonska živila, kupovale na tržnici, jih predelale in konzervirale, da so ustvarile zalogo za večji del leta. Konzervirana in predelana živila so shranjevale v shrambi. Danes je ponudba hrane neprimerno 
večja, oskrbujemo se sproti, zato poseben prostor za shranjevanje živil ni več potreben. Na voljo je veliko na pol predelane hrane, ki jo je potrebno doma le še dokončati. Funkcijo shrambe sta prevzela hladilnik in kuhinjska omara. Pomenljiv je tudi položaj shrambe - praviloma je bila v severnem delu stanovanja, dostopna iz kuhinje, redkeje tudi iz predsobe, površina shrambe je znašala med 2 in $3 \mathrm{~m}^{2}$.

Prostor, ki ga v stanovanjih iz konca 20. st. ne najdemo več, je bivalna kuhinja, čeprav je bila v začetku stoletja središče stanovanja, kjer se je odvijala večina družinskega življenja. Bila je kuhinja, jedilnica in dnevna soba v enem. To velja le za manjša meščanska stanovanja, v večjih je bila kuhinja namenjena samo pripravi hrane. Drugi del dnevnega življenja se je odvijal v salonu, v kadilnici, v knjižnici ali jedilnici. S specializacijo prostorov, ki se je zgodila sredi 20. st., je iz bivalne kuhinje nastalo več ločenih prostorov. Kuhinja je bila odtlej namenjena samo pripravi hrane. V nekaterih stanovanjih je v kuhinji ostal še jedilni kot, najpogosteje pa je bila jedilnica del dnevne sobe. Danes je pripravi hrane namenjen kuhinjski kot, ki je del večjega bivalnega prostora. Priprava na pol pripravljene hrane ne potrebuje tolikega prostora, na voljo so številni gospodinjski pripomočki, ki jih je mogoče uporabiti na majhnem prostoru.

V tlorisih stanovanj iz konca prejšnjega stoletja je več prostorov, ki jih v stanovanjih iz prve polovice 20. st. ni bilo ali pa so imeli povsem drugačno funkcijo. Eden takih je balkon oziroma loža. Balkoni so sicer bili del bogatejših meščanskih stanovanj, vendar je bila njihova funkcija povsem drugačna od današnje. Namenjeni so bili odlaganju stvari, zato so bili umeščeni v bližino kuhinje in ni bilo potrebe, da bi bili prav veliki. Ob koncu stoletja je funkcija balkona postala povsem drugačna, postal je del bivalnega prostora, ki omogoča vizualni in doživljajski stik z okolico, za oboje pa je potrebna tudi ustrezna velikost oziroma površina.

Večja stanovanja iz 90. let so opremljena z garderobno sobo, prej je bila spalnica prostor za shranjevanje garderobe, kjer se oblečemo in uredimo. Danes garderobo vse pogosteje shranjujemo v posebnem prostoru, ki je dostopen iz predsobe. Morda je vzrok temu večje število oblačil, preglednejše shranjevanje v različnih tipih omar, vsekakor je to znak večjega blagostanja, naraščajočega individualizma in spremenjenega vedenja ljudi, ki svoj socialni položaj potrjujejo tudi z izbiro oblačil. Nekoč so imela torej stanovanja poseben prostor za shranjevanje živil, danes imajo poseben prostor za shranjevanje oblačil.

Del večjih stanovanj je vse pogosteje tudi utility, kamor so se preselile dejavnosti iz (bivalne) kuhinje; tudi ta se pojavlja v stanovanjih iz 90. let. Zdi se, da je ta 'gospodinjska delavnica' posledica želje, morda obsedenosti po čistem stanovanju, po ločitvi funkcionalnih prostorov od reprezentančnih, in zato vse večje specializacije posameznih delov stanovanja.

Stanovanja iz začetka in konca 20. st. se ne razlikujejo zgolj po vrsti prostorov, temveč tudi po spremenjenem razmerju med površino posameznega prostora in površino stanovanja. Nekateri prostori so se v času od začetka do konca stoletja povečali, drugi zmanjšali. Največje spremembe so pri kuhinji, kopalnici, dnevni sobi in predsobi. Razmerje med velikostjo prostorov določa zasnovo oziroma razmestitev prostorov v stanovanju. Zaradi manjše predsobe je več sob prehodnih, zaradi manjše kuhinje postaja dnevna soba večfunkcionalni prostor, zaradi večje dnevne sobe je manjša površina ostalih sob (otroške sobe, spalnice, delovne sobe). 
Preglednica 1: Spremembe vrste in velikosti posameznih delov stanovanja v 20. st. Table 1: Changes in type and size of certain parts of apartment during the 20th century

\begin{tabular}{|l|l|l|l|}
\hline $\begin{array}{l}\text { Prostori, ki se } \\
\text { povečujejo }\end{array}$ & $\begin{array}{l}\text { Prostori, ki se } \\
\text { zmanjšujejo }\end{array}$ & $\begin{array}{l}\text { Vse redkeje del } \\
\text { stanovanja }\end{array}$ & $\begin{array}{l}\text { Vse pogosteje del } \\
\text { stanovanja }\end{array}$ \\
\hline $\begin{array}{l}\text { dnevna soba } \\
\text { kopalnica } \\
\text { balkon }\end{array}$ & $\begin{array}{l}\text { bivalna kuhinja } \\
\text { soba } \\
\text { predsoba } \\
\text { spalnica }\end{array}$ & $\begin{array}{l}\text { shramba } \\
\text { WC in kopalnica skupaj } \\
\text { bivalna kuhinja } \\
\text { soba za gospodinjsko } \\
\text { pomočnico }\end{array}$ & $\begin{array}{l}\text { utility } \\
\text { dve kopalnici } \\
\text { kuhinjski kot } \\
\text { velik bivalni prostor } \\
\text { garderobna soba } \\
\text { jedilnica }\end{array}$ \\
\hline
\end{tabular}

\subsection{Epicenter stanovanja - najprej kuhinja, kasneje dnevna soba}

Kateri je osrednji prostor v stanovanju danes in kateri je bil v preteklosti? Upoštevaje položaj in velikost, je v začetku stoletja osrednje mesto pripadalo kuhinji, danes pa dnevni sobi. V stanovanjih iz začetka 20. st. je bila kuhinja osrednji in največji prostor stanovanja, saj je imel največ funkcij. Pri tem je potrebno razlikovati stanovanja za višji in nižji sloj. Pri prvih največji prostor ni bila kuhinja, temveč salon, povezan z jedilnico, kar je kasneje postala dnevna soba. Bivalna kuhinja je bila praviloma del delavskih stanovanj in je služila kot prostor za pripravo hrane, druženje, počitek, igre otrok in številna druga hišna opravila. V njej je bilo veliko različnih kosov pohištva, poleg štedilnika in nekaj kuhinjskih omar še jedilna miza, kavč, kredenca. Velikost kuhinj v meščanskih in delavskih stanovanjih se sicer ni bistveno razlikovala, merila je med 20 in $25 \mathrm{~m}^{2}$, vendar je kuhinja v delavskih stanovanjih imela veliko več funkcij, bila je večfunkcionalni prostor. V obravnavanih stanovanjih iz začetka stoletja je kuhinja obsegala 15-20 \% površine stanovanja, v stanovanjih iz konca stoletja pa le še 7-12 \%. Razmerje med površino kuhinje in dnevne sobe je bilo v začetku stoletja $13: 25 \mathrm{~m}^{2}$, v drugi polovici stoletja $11: 16$ $\mathrm{m}^{2}$, ob koncu stoletja $11: 18$, pa tudi $6: 27 \mathrm{~m}^{2}$.

Slika 4: Spreminjanje površine dnevne sobe (levo) in kuhinje v 20. st. (desno) Figure 4: Changes of size of living room (left) and kitchen in 20th century (right)
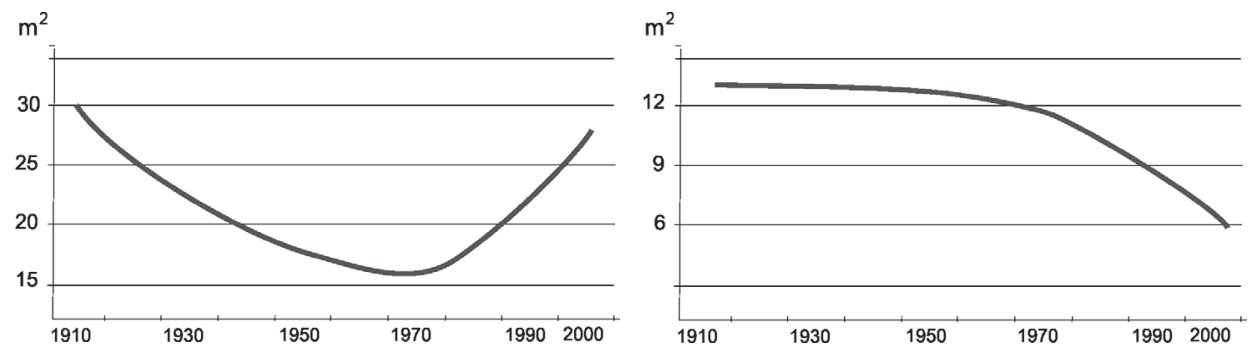
V stanovanjih iz 70. in 80. let so bivalne kuhinje nadomestile skandinavske kuhinje, v stanovanjih iz konca 20. st. pa kuhinje kot ločenega, posebnega prostora praviloma ni več, pač pa je nastal kuhinjski kot v dnevni sobi. Prostor za pripravo hrane (kuhinjski kot) je postal del bivalne, dnevne sobe, saj za pripravo že na pol pripravljene hrane velik prostor ni več potreben. Zaradi tehnične opremljenosti stanovanj iz konca stoletja je mogoče vonj in množico kuhinjskih pripomočkov nevtralizirati do te mere, da niso več moteči za opravljanje drugih dejavnosti.

(Bivalno) kuhinjo kot osrednji prostor stanovanja je tako nadomestila dnevna soba s kuhinjskim kotom. Danes je dnevna soba osrednji del stanovanja, saj je zaradi velikosti in opremljenosti namenjena vsem generacijam oziroma članom družine. Ostale sobe se spreminjajo v prostore za počitek, imajo bolj ali manj določen namen. Dnevna soba je zato še večja: v stanovanjih iz začetka 20. st. je zavzemala okoli 20 \% površine stanovanja, do konca stoletja pa se je delež povečal na več kot $25 \%$. Vse več je stanovanj, kjer je velika dnevna soba pregrajena s kosi pohištva ali delnimi stenami na dva ali tri dele: jedilnico, prostor za počitek in razvedrilo, v večjih stanovanjih še delovni del. Jedilni del je bil še v drugi polovici stoletja bližje kuhinji, ob koncu stoletja pa je, po opremi in dostopnosti sodeč, bližje dnevni sobi.

\subsection{Sobe in specializacija prostorov}

V stanovanjih iz začetka stoletja so bile vse (bivalne) sobe približno enako velike, ne glede na namembnost. Izjema je bila soba za gospodinjsko pomočnico, ki je bila precej manjša od ostalih. Tudi prehodnost sob je bila veliko bolj običajna, kot je to primer v stanovanjih iz kasnejših obdobij. Oboje lahko pripišemo duhovni dediščini stanovanj iz bolj oddaljene preteklosti. Nekoč je bilo bivališče predvsem zatočišče pred zunanjim svetom, manj kraj, kjer bi človek živel, se zadrževal večino dneva in pri tem počel najrazličnejše stvari. Kot navaja Selle (2011, str. 85), je bil sprva v stanovanjih pomemben topel, ogrevan prostor ter prostor za osebno higieno; obe zahtevi sta bili izpolnjeni v enem in istem prostoru. Ker je takrat gospodinjstvo obsegalo več članov, ki so tvorili tako imenovano veliko družino, je bila vsaka soba večnamenski prostor. V stanovanjih iz 19. st. so se še ohranile velike sobe brez točno določene namembnosti, npr. prostor za nočni počitek je čez dan lahko služil poslovni dejavnosti ali pa hrambi predmetov skupnega gospodinjstva. Ferleževa navaja (2009, str. 219), »».. da so se vsaj v večjih sobah še sredi 19. st. prepletale različne funkcije, zlasti pa dnevno bivanje in spanje.«

Ker je vsaka soba služila različnim namenom, so bile sobe enako velike. Tudi zasebnost družinskih članov še ni bila tako močno izražena, zato ni motilo, če so bile sobe prehodne. Prehodnost ene ali dveh sob je pomenila tudi racionalnejši tloris stanovanja, saj je lahko bil hodnik, iz katerega so bile dostopne ostale sobe, manjši. V tlorisih stanovanj iz druge polovice 20. st. pa je velikost sob različna glede na namembnost. Dnevna soba je bila največja, spalnica in kuhinja manjši, otroška soba najmanjša. Funkcionalizem in racionalizem, postulata industrijskega obdobja, sta v zasnovo stanovanja vnesla diferenciranost glede na dejavnost, ki jo posameznik v stanovanju opravlja. Spalnica je namenjena samo nočnemu počitku, zato je lahko manjša od dnevnega, bivalnega prostora. $\mathrm{K}$ 
temu je prispeval še vse bolj prisoten individualizem, ki vsebuje težnjo po zasebnosti in prostorski odmaknjenosti. Tudi izdelovalci stanovanjske opreme so prispevali svoj delež $\mathrm{s}$ tem, da so za vsak prostor razvili drugačno pohištvo. Takšno razmerje se je z manjšimi korektivi ohranilo še v tlorisih stanovanj iz konca 20. st, zaradi različne velikosti sob pa se je površina celotnega stanovanja v povprečju zmanjšala.

Za ponazoritev si oglejmo sobo, ki jo uporabljamo kot spalnico. Pri tem je potrebno razlikovati med manjšimi, npr. dvosobnimi stanovanji, in večjimi, npr. trisobnimi stanovanji. V slednjih se pogosto pojavlja garderobna soba, ki je umeščena v ali ob spalnico. Če jo upoštevamo kot del spalnice, se površina povečuje, sicer pa se velikost spalnice od leta 1980 zmanjšuje, kar lahko opazujemo v dvosobnih stanovanjih. Spalnica v stanovanjih iz začetka 20. st. je merila okoli $25 \mathrm{~m}^{2}$, ob koncu opazovanega obdobja pa le še 15 do $20 \mathrm{~m}^{2}$. Zmanjševanje površine je vidno tudi pri otroških sobah, ki so se od nekdanjih $25 \mathrm{~m}^{2}$ zmanjšale na okoli $15 \mathrm{~m}^{2}$. Razmerje med površino dnevne sobe in spalnice je bilo v začetku stoletja $27: 25 \mathrm{~m}^{2}$, sredi stoletja $21: 15 \mathrm{~m}^{2}$, ob koncu stoletja pa $28: 12 \mathrm{~m}^{2}$.

\subsection{Balkon - sprva prostor za gospodinjska opravila, kasneje za oddih}

Balkon je v sto letih doživel veliko prevrednotenje. Sprva je imel predvsem gospodinjsko funkcijo za odlaganje, hlajenje, čiščenje, stepanje, zato je bil umeščen v bližino kuhinje ali vhoda v stanovanje. Danes je balkon prostor oddiha, kjer si stanovalci privoščimo svež zrak, uživamo v razgledu, počivamo. Balkon je praviloma povezan z dnevno sobo, je njen podaljšek, po tlorisih sodeč pa je bil v 70. in 80 . letih pogosto povezan tudi s spalnico, redkeje s kuhinjo. Površina balkona se povečuje, kar je verjetno povezano z več funkcijami, ki jih ima danes v primerjavi s tistimi iz začetka stoletja. V stanovanjih iz 30. let (prej je imelo balkon le redkokatero stanovanje) je ta meril 4-5 $\mathrm{m}^{2}$, sredi stoletja okoli $4 \mathrm{~m}^{2}$, ob koncu pa $6-10 \mathrm{~m}^{2}$.

Zdi se, da je velikost balkona eden od pokazateljev luksuznega stanovanja. Ker potreba po odlaganju in čiščenju še vedno obstaja, ima veliko stanovanj dva balkona, gospodinjskega ob kuhinji in drugega, ki je povezan z dnevno sobo. Še posebej je to razvidno $\mathrm{v}$ tlorisih iz 60. in 80. let, ki so zasnovani zelo funkcionalno in racionalno. Spremenil se je tudi tip tega 'stika z zunanjim svetom'. V začetku stoletja je bila večina stanovanj opremljena $\mathrm{z}$ balkonom, ki je bil pritrjen na fasado stavbe in sestavljen iz tal in ograje. $\mathrm{V}$ drugi polovici 20. st., še posebej pa ob koncu stoletja, je balkon nadomestila loža, ki je pravzaprav soba brez zunanje stene. Zaradi tega je prostor bolj zaščiten pred vremenom, pa tudi pred pogledi sosedov. Intimnost, zasebnost, sproščenost je s tem večja, prostor pa bolj uporaben. Intenzivnejši stik z naravo je ena od značilnosti sodobnega bivanja, čemur je namenjen tudi balkon oziroma loža.

\subsection{Predsoba - nekoč reprezentativen prostor, kasneje podaljšek vhoda}

Položaj in namen predsobe (hodnika) je prav tako poveden: v stanovanjih iz začetka stoletja je bila predsoba sprejemnica, reprezentativen prostor, prvi vtis obiskovalca o stanovanju in stanovalcih. Morda je bila zato tako velika, da jo je bilo možno opremiti z 
reprezentativnim pohištvom in stenskim okrasjem. Poleg tega je bila prostor, ki je povezoval vse druge sobe. Umeščena je bila na sredo stanovanja tako, da sta se na obe strani preslikala zelo podobna tlorisa: na eno, običajno severno stran, kuhinja in drugi 'servisni' (pomožni) prostori, na drugo, običajno južno stran, pa dnevni in bivalni prostori. Del takratne meščanske kulture je bilo obiskovanje, kar je morda tudi prispevalo k reprezentativni ureditvi vstopa $\mathrm{v}$ stanovanje. $\mathrm{K}$ takšnemu sklepu nas napeljujejo tlorisi stanovanj nižjih socialnih slojev, ki so bili brez predsobe. Iz zunanjega hodnika je obiskovalec stopil naravnost v (bivalno) kuhinjo.

Že v stanovanjih iz sredine stoletja je predsoba precej manjša. Iz prvotnih $12-17 \mathrm{~m}^{2}$ se je zmanjšala na 5-10 m², hkrati se je spremenila tudi zasnova stanovanja. V starih meščanskih stanovanjih je bila večina sob dostopnih iz hodnika oziroma predsobe, kasneje to ni bilo več pravilo. Predsobe v stanovanjih iz konca 20. st. omogočajo vstop samo v pomožne prostore ter eno ali dve sobi, funkcijo 'razvoda' pa je v novejših stanovanjih prevzela dnevna soba. Ob koncu stoletja je predsoba le še predprostor, kamor vstopimo. Ker je veliko manjša, jo tudi hitro zapustimo. V sodobnih predsobah je prostora zgolj za garderobno omaro, vsa druga reprezentativna sporočila so v dnevni sobi. Umaknjena je na rob stanovanja, ob servisne prostore, zato je več sob prehodnih. Obroben položaj predsobe je razviden v tlorisih iz 70 . in 80. let, ko so postala stanovanja funkcionalno zasnovana.

\subsection{Kopalnica - osebna higiena in skrb za telo}

Tudi položaj in velikost kopalnice kažeta na spremembe v načinu bivanja zadnjih sto let. V začetku 20. st. je bilo le redko katero stanovanje opremljeno s kopalnico. Osebni higieni je bila namenjena kuhinja, spalnica ali ena od sob, v kateri je bil pripravljen vrč z vodo in umivalnik. Obstajala so še javna kopališča, kamor so ljudje odhajali enkrat tedensko. Le v redkih meščanskih stanovanjih iz začetka stoletja je bila tudi kopalnica. Šele v 30. letih, ko se je v Mariboru, podobno kot v drugih mestih, začelo graditi vodovodno in kanalizacijsko omrežje, je kopalnica postala standardni del stanovanja. Takrat so jo običajno preuredili iz drugega prostora, npr. iz sobe za služkinjo ali iz shrambe, zato je položaj kopalnice v starejših stanovanjih zelo različen, pogosto tudi nenavaden. Površina kopalnice je znašala med 5 in $7 \mathrm{~m}^{2}$. Ker je v večino stanovanj kopalnica prišla kasneje kot stranišče, sta nastala ločena prostora, lahko tudi vsak v svojem delu stanovanja. Šele v novih objektih je prišlo do spremembe.

V stanovanjih, zgrajenih sredi stoletja in pozneje, je bila kopalnica v nočnem delu stanovanja, skupaj s straniščem. Takšna rešitev je bila tehnično enostavnejša in cenejša, zato se je uveljavila v skoraj vseh novogradnjah. Stanovanjski bloki so bili takrat grajeni po tipskih načrtih, zato najdemo enotno rešitev oziroma tlorisno zasnovo v številnih stanovanjih. Površina kopalnice je znašala med 5 in $7 \mathrm{~m}^{2}$, kar je predstavljalo do $6 \%$ površine stanovanja. V stanovanjih iz konca stoletja so kopalnice nekoliko večje, od 5-8 $\mathrm{m}^{2}$. Iz prvotnih 5-6 \% je delež površine narasel na 7-8 \%. Večja površina je najbrž povezana s povečano vlogo tega prostora, v njem se zadržujemo dalj časa, pomnožila se je tudi kopalniška oprema. Sociologi opažajo, da vse več časa porabimo za nego telesa in vzdrževanje telesne higiene. Poleg drugega umivalnika so v kopalnici pogosto še kabina 
za tuširanje, pralni in sušilni stroj, omara za perilo. V stanovanjih, kjer je poleg kopalnice še delovni prostor (utility), je površina kopalnice nekoliko manjša, vendar kljub temu večja kot na začetku stoletja.

Slika 5: Spreminjanje površine spalnice (levo) in kopalnice v 20. st. (desno)

Figure 5: Changes of size of bedroom (left) and bathroom in 20th century (right)
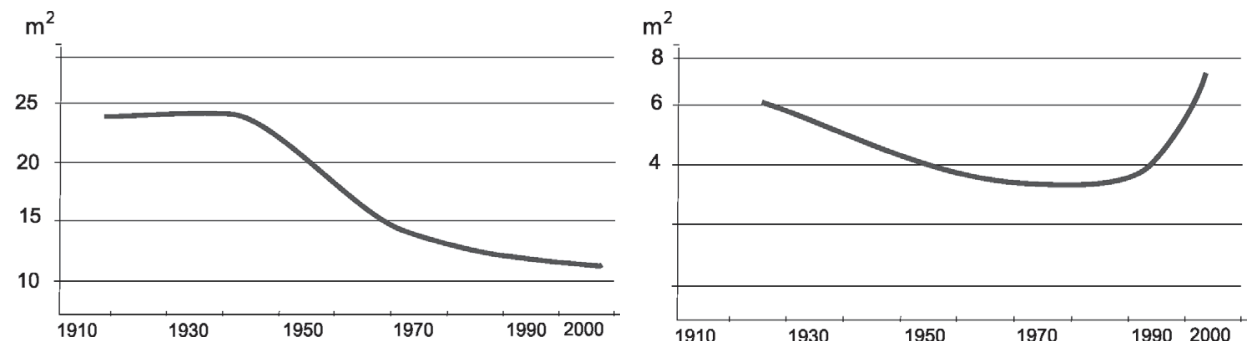

\subsection{Stranišče}

Velikost tega prostora se je najmanj spremenila, površina običajno ni bila manjša od $1 \mathrm{~m}^{2}$ in ne večja od $2 \mathrm{~m}^{2}$. Spremenil se je tudi njegov položaj. V delavskih hišah iz začetka 20. st stranišče ni bilo v vsakem stanovanju, pač pa je več gospodinjstev uporabljalo skupno stranišče, ki je bilo na stopnišču oziroma hodniku. V meščanskih stanovanjih pa je bilo stranišče umaknjeno od dnevnih prostorov, še posebej od jedilnice oziroma salona. Vzrok za to je zagotovo povezan z načinom odvajanja odplak. Prvotna stranišča so delovala na t. i. štrbunk. Zato je bil v stanovanjih višjih socialnih slojev pred straniščem še predprostor, ki je povečal zasebnost in odmaknjenost od drugih delov stanovanja. Konec stoletja tega tudi v luksuznih stanovanjih ni več. V 60. letih sta se pričela pojavljati stranišče in kopalnica $v$ istem prostoru in takšna ureditev je prevladovala še v 80. letih. Stranišče je bilo umeščeno $v$ dnevni del stanovanja, v bližino vhoda ali kuhinje. V 80. letih se je takšna praksa spremenila. Stranišče je pogosteje umeščeno v nočni del stanovanja, $\mathrm{v}$ bližino kopalnice in spalnice.

\subsection{Tehnične rešitve pred naravnimi}

V tlorisih stanovanj iz začetka 20. st., tako delavskih kot meščanskih, je opazno, da so kuhinja, shramba, pogosto tudi spalnica v severnem delu stanovanja, na sončni, južni ali zahodni strani, pa dnevna soba in drugi bivalni prostori. Danes takšna razporeditev ni več pravilo. Zaupanje v tehnične zmožnosti hlajenja ali ogrevanja prostorov je prevladalo nad naravnimi načini. Še bolj je to očitno pri položaju kopalnice, stranišča in kuhinje. Zračenje toaletnih prostorov, v katerih je bilo v začetku stoletja praviloma okno, danes prevzemajo ventilatorji in zračniki. Rezultat je večja poraba energije, več hrupa in zahtevnejše vzdrževanje. Naravne razmere vse manj določajo razporeditve prostorov, zdi se, da postaja pomembnejša racionalnost tlorisa, od zunanjih dejavnikov pa osončenost, razgled oziroma vidni stik z okolico. 


\section{ZAKLJUČEK}

Bivanje je ena od temeljnih človekovih dejavnosti, stanovanje pa je prostorska materializacija bivanja. Zasnova stanovanja je odraz družbenih razmer, kar pomeni, da se v tlorisu (prostoru) kažejo temeljne socialne, kulturne in ekonomske značilnosti vsakokratne družbe ter predstave o tem, kako posamezne dejavnosti umestiti v prostor - stanovanje. Hkrati je stanovanje odraz socialnih in kulturnih lastnosti stanovalca, kar pomeni, da se v opremi stanovanja odslikava stanovalčevo razumevanje bivanja in način, kako to uprostoriti. Oba vidika sta prostorsko, socialno in kulturno relevantna, vendar še slabo preučena. V prispevku smo primerjali tlorise stanovanj iz različnih obdobij prejšnjega stoletja. Pokazali smo, da se je tloris stanovanj spreminjal, kar smo povezali s spreminjanjem družbenih okoliščin.

Iz primerjave tlorisov stanovanj je razvidno, da sta se zasnova stanovanja in razporeditev prostorov od začetka do konca 20. st. precej spremenila. Nekaj prostorov je nastalo na novo, npr. kopalnica, utility, dnevna soba s kuhinjskim kotom, nekaterih v novih stanovanjih ni več (shramba, bivalna kuhinja). Spremenila se je tudi velikost prostorov oziroma delež posameznega prostora v površini stanovanja. V sodobnih stanovanjih je kuhinja veliko manjša, kot je bila na začetku stoletja, dnevna soba pa večja; manjša je spalnica, večja sta kopalnica in balkon. V grafičnih upodobitvah smo prepoznali tri tipe tlorisov. Eden je iz začetka 20. st., drugi iz začetka druge polovice, tretji je nastal ob koncu stoletja.

Spremembe tlorisa stanovanj je mogoče povezati s splošnimi družbenimi značilnostmi, in sicer z značilnostmi meščanske družbe, družbo socialne enakosti v socialističnem obdobju ter sodobnim pojavom individualizma in blagostanja (potrošništva). Zasnova stanovanj ter velikost prostorov sta odraz razmer, v katerih so bila zgrajena, deloma velja to tudi za opremo stanovanja, čeprav je pri tem bolj odločujoč socialni položaj stanovalca. Meščansko stanovanje (tip A) je odraz patriarhalnih socialnih odnosov, vrednot in načina življenja tistega časa ter arhaične zasnove stanovanja, ko so bili vsi prostori približno enako veliki in zato primerni za vsako namembnost. Osrednji prostor je bila bivalna kuhinja (v stanovanjih nižjega sloja) oziroma salon, knjižnica ali jedilnica (v stanovanjih meščanov). Stanovanje iz sredine 20. st. (tip B) je po zasnovi podobno meščanskim stanovanjem, vendar razporeditev in velikost prostorov kažeta vpliv funkcionalistične miselnosti. Sobe niso več enako velike, kajti namembnost vsake sobe je določena že vnaprej, osrednje mesto pa pripada dnevni sobi. Razdeljeno je na dnevni in nočni del. Ob koncu stoletja je v tlorisih stanovanj mogoče prepoznati vseprisoten individualizem, socialno heterogenost, spremenjen način življenja. Dnevna soba, ki ima po novem izrazito družabno funkcijo, je razdeljena na več 'kotov', npr. kuhinjski kot, igralni kot, medijski kot. Soba je zato velika in je osrednji prostor stanovanja. Velik je tudi balkon, ki povezuje bivanje z zunanjim okoljem. Na račun tega so se zmanjšali prostori, ki jih ne uporabljamo tako pogosto, npr. spalnica ali otroška soba. 


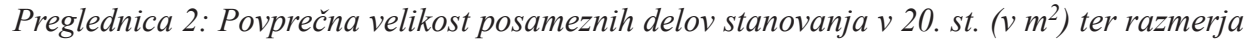
med velikostjo prostorov

Table 2: Average size of individual rooms and the proportions between them during the 20th century $\left(\right.$ in $\left.\mathrm{m}^{2}\right)$

\begin{tabular}{|l|c|c|c|}
\hline Prostor & Začetek 20. st. & Sredina 20. st. & Konec 20. st. \\
\hline Predsoba & $12-17$ & $5-10$ & $2-9$, tudi brez \\
\hline Dnevna soba & $20-25$ (jedilnica) & $17-23$ & $20-27$ \\
\hline Kuhinja & $14-20$ & $10-14$ & $6-15$ \\
\hline Spalnica & $20-25$ & $15-20$ & $13-17$ \\
\hline Soba & $15-23$ & $13-18$ & $15-17$ \\
\hline Balkon & $4-5$ & $5-7$ & $6-10$ \\
\hline Kopalnica & $5-7$ & $5-7$ & $5-8$ \\
\hline Stranišče & $1,5-2$ & $1,5-2$ & $1,5-2$ \\
\hline Trisobno stanovanje & $90-120$ & $60-80$ & $70-90$ \\
\hline $\begin{array}{l}\text { Razmerje med površino kuhinje in } \\
\text { dnevne sobe }\end{array}$ & $13: 25$ & $11: 20$ & $11: 22 ; 6: 27$ \\
\hline $\begin{array}{l}\text { Razmerje med površino dnevne sobe in } \\
\text { spalnice }\end{array}$ & $25: 23$ & $20: 15$ & $27: 15$ \\
\hline
\end{tabular}

\section{Viri in literatura}

Baudrillard, J., 2007. Das System der Dinge: über unser Verhältnis zu den alltäglichen Gegenständen. 3. izdaja. Frankfurt am Main, Campus, 264 str.

Bourdieu, P., 1987. Die feinen Unterschiede: Kritik der gesellschaftlichen Urteilskraft. Frankfurt am Main, Suhrkamp Taschenbuch, 910 str.

Ferlež, J., 2009. Stanovati v Mariboru: etnološki oris. Maribor, Umetniški kabinet Primož Premzl, 335 str.

Gradbena dokumentacija stanovanjskih hiš Cankarjeva 14, Krekova 21, Razlagova 2, Gregorčičeva 31, Veljka Vlahovića 51, Ulica Eve Lovše 8. 2014. Pokrajinski arhiv Maribor.

Hasse, J., 2009. Unbedachtes Wohnen: Lebensformen an verdeckten Rändern der Gesellschaft. Bielefeld, Transcript, 251 str.

Häußermann, H., Siebel, W., 1996. Soziologie des Wohnens: eine Einführung in Wandel und Ausdifferenzierung des Wohnens. München, Juventa Verlag, 352 str.

Helten, F., 2002. Vernetztes Wohnen zwischen Wunsch und Wirklichkeit: was hält Otto Normalverbraucher vom Smart Home?. V: Döllman, P., Temel, R. (ur.). Lebenslandschaften: zukünftiges Wohnen im Schnittpunkt von privat und öffentlich. Frankfurt am Main, Campus, str. 61-71.

Müller, W., 1979. Städtebau. Stuttgart, B. G. Teubner, 624 str.

Pirkovič-Kocbek, J., 1982. Izgradnja sodobnega Maribora: mariborska arhitektura in urbanizem med leti 1918 in 1976. Ljubljana, Partizanska knjiga, 100 str. 
Prigge, W., 2002. Befreites Wohnen? V: Döllman, P., Temel, R. (ur.). Lebenslandschaften: zukünftiges Wohnen im Schnittpunkt von privat und öffentlich. Frankfurt am Main, Campus, str. 190-196.

Selle, G., 2002. Innen und Aussen: Wohnen als Daseinentwurf zwischen Einschliessung und erzwungener Öffnung. V: Döllman, P., Temel, R., (ur.). Lebenslandschaften: zukünftiges Wohnen im Schnittpunkt von privat und öffentlich. Frankfurt am Main, Campus, str. 209-229.

Selle, G., 2011. Die eigenen vier Wände: Wohnen als Erinnern. Berlin, form+zweck, 265 str.

Studen, A., 1995. Stanovati v Ljubljani: socialnozgodovinski oris stanovanjske kulture Ljubljančanov pred prvo svetovno vojno. Ljubljana, ISH, 226 str.

Tuan, Y., 2004. Home. V: Harrison, S., Pile, S., Thrift, N. (ur.). Patterned ground: entanglements of nature and culture. London, Reaction Books, str. 164-165.

\section{TRANSFORMATION OF THE 20TH CENTURY APARTMENT GROUND PLANS (MARIBOR CASE)}

\section{Summary}

Apartment is a space where we live and living is one of the basic human activities. So far, living and apartments have been discussed in an obscure and relatively simple way: living with statistical data on number of inhabitants and neighbourhood characteristics, while an apartment hardly ever entered geography as an object of cognition. An apartment is testimonial from at least three different angles: as a physical formation, manifested in the ground plan and being a result of social, economic and cultural circumstances in the society; as a social phenomenon, where equipment and lifestyle come forward, judged on time and region. An apartment is at the same time a reflection of economic, technological, cultural and social circumstances in the society, as well as economic, social and cultural characteristics of the inhabitants.

To determine characteristics of apartment ground plans, one must select elements which enable comparison and according to which apartments from different periods differ from the previous century. This was based on the apartment function and data available from ground plans. The type and size of premises, and the relations between them and their change through decades, seem to be the key characteristics. The following elements were therefore defined as relevant:

- Type and size of ground plans in the apartment;

- Proportion between the size of the kitchen and the living room;

- Proportion between the size of the living room and the bedroom;

- Percentage of bathroom size within the apartment;

- Percentage of the kitchen size within the apartment;

- Percentage of the living room size within the apartment;

- Percentage of the bedroom size within the apartment;

- Rooms without daylight;

- Number of walk-through rooms (with no access from the corridor);

- Separated night and day part of the apartment. 
When getting to know ground plans of apartments from the previous century, the analysis brought forward three types that coincide with three social classes: the first half of the 20th century, in the social sense defined by bourgeoisie and industrialization; the middle of the second half of the previous century, defined by the socialist system and social equality; and the end of the previous century, defined by increased individualism and consumerism. This is not a periodization of the previous century, but rather just a point of reference for showing changes in ground plans.

\section{Apartment type A}

The first half of the previous century was defined by bourgeoisie and the appertaining culture, linked to new economic activities, stores, services, administrative offices, new forms of division of labour, new values and new types of apartment which had not been known before. An apartment from the beginning of the century has a symmetrical ground plan; the axis of symmetry being represented by the anteroom or a long corridor, with rooms to each side. This layout can also be called the corridor apartment type. The apartment is furthermore oriented in the north-south direction, all rooms have daylight. Rooms are also spacious, without any previously designated purpose. The kitchen is an independent room which in smaller apartments also served as the main living area, while bigger apartments had a dining room. This type of ground plan shows the layout of bourgeoisie apartments from the 19th century which kept long until 1950s. Corridor type apartment is linked to a special type house, namely to the multi-apartment bourgeoisie and workers' house.

\section{Apartment type B}

The second half of the previous century was defined by the socialist system. Instead of social stratification, this era brought forward social equality. Social housing almost disappeared in this time, being replaced by uniform and unified apartments in blocks of flats and new urban houses. Ground plan from the second half of the previous century has several characteristics: the central apartment area was no longer the (residential) kitchen or a dining room but the living room. From there, one could enter almost all other rooms - a function of the anteroom from the past. The anteroom was no longer an axis, running lengthwise, but the entry point to the apartment. It lost its representativeness and gained functionality. The number of interconnecting rooms therefore increased, while not all areas kept daylight due to new layout. Also typical for this ground plan type are different-size rooms, where the purpose defines the size. The dining room became part of the kitchen or living room and was no longer an independent room. The day and night part of the apartment were less strictly separated. This type of ground plans could be found between 1950 and 1985-1990; one could name it the central apartment type where rooms are arranged around the living room. 


\section{Apartment type C}

The ground plan of apartments which appeared at the end of the century shows social heterogeneity and differentiation, wellbeing and consumerism, increased individualism and a large move of the personal life into the apartment. The latter became a place of work, fun, entertainment and socializing, experience, polifunctional area where people spend a lot of time and perform more activities than decades ago. Modern apartments typically have a large common space that replaced individual rooms, typical for apartments from the previous century. The apartment is more open, but provides less privacy to its occupiers. Rooms that were once separated (working room, children's room) are now covered with corners (such as working corner, media corner), separated with partial walls or furniture. This type has more specialized rooms that did not exist before, which are now meant for specific purposes (such as utility, wardrobe room). The apartment appears open and bright, which comes from glass walls and large windows that provide connection to the environment. The ratio between the sizes of the kitchen in relation to the living room now turns toward the latter. A suitable name for this type could be an open apartment type with a large central room.

In the paper, some changes of apartment ground plans during the 20th century have been defined, like changes in apartment surface, the epicentre of the apartment, the specialization of rooms, changed position of the balcony, anteroom, bathroom and toilet and the meaning of technical systems that replace the natural solutions. Comparing ground plans of apartments shows that the design of the apartment and layout of rooms changed considerably during the last century. Some rooms were added, some others no longer exist. What also changed is the size of the room or the percentage according to the total surface. Graphic representation shows three types of ground plans: one is from the beginning of the century, the other from the middle and the third from the end of the century. Changes of the ground plan can be linked to social characteristics, namely characteristics of the bourgeois society, socialist system of social equality and the modern phenomenon called individualism and social wellbeing (consumerism).

(Translated by Tanja Angleitner Sagadin, M.Sc.) 